Article Review

\title{
Minireview: Formulasi Obat Kumur Ekstrak Daun Ketul (Bidens pilosa)
}

\author{
Gracelynn Meira ${ }^{1}$, Assidiq Zidane Irwansyah ${ }^{1}$, Hadinata Santoso $^{1}$, Mariana Wahjudi ${ }^{1 *}$ \\ ${ }^{1}$ Prodi Biologi, Fakultas Teknobiologi, Universitas Surabaya, Raya Kalirungkut, Surabaya-Indonesia \\ 60293 \\ * corresponding author: mariana_wahyudi@staff.ubaya.ac.id
}

\begin{abstract}
Ketul (Bidens pilosa L) is weed plant that has antibacterial properties. The potential of this plant has not been developed yet in Indonesia. We conducted a literature study about this plant use for herbal mouthwash. The purposes of this study were to determine components of Ketul leaf with antibacterial activity, to know the extraction solvent, to determine the method for antibacterial activity, and to predict the characteristics and components of herbal mouthwash formula. The results showed that Ketul leaf contains tannins, cardiac glycosides, saponins, alkaloids, flavonoids, and terpenoids which could inhibit the growth of various bacteria, including Streptococcus mutans. Hence the mouthwash is predicted to have antibacterial activity. The safe extraction solvent widely used was $70-80 \%$ ethanol. The Ketul leaf extract has the potential to be applied in herbal mouthwash formula. Other characteristic can be adjusted to meet the requirements as herbal mouthwash, which are pH between 5-7, the viscosity value near water viscosity value $(1 \mathrm{cP})$, stable during storage, and color is brownish yellow. Some common additives were added in mouthwash to improve the flavors and taste, such as sorbitol, tween-80, peppermint oil, and sodium benzoate.
\end{abstract}

Keywords: antibacterial activity, solvent, streptococcus mutans, weed

\begin{abstract}
Abstrak-Ketul (Bidens pilosa L) merupakan tumbuhan gulma yang memiliki aktivitas antibakteri. Potensi tumbuhan ini belum banyak dikembangkan di Indonesia. Pada tulisan ini telah dilakukan kajian pustaka pemanfaatan Ketul untuk obat kumur herbal. Tujuan kajian ini adalah untuk mengetahui komponen ekstrak daun Ketul yang berkhasiat antibakteri, mengetahui pelarut ekstraksi, metode penentuan aktivitas antibakteri obat kumur, dan prediksi karakteristik dan komponen obat kumur herbal daun Ketul. Hasil penelusuran pustaka menunjukkan bahwa daun Ketul mengandung tannin, glikosida jantung, saponin, alkaloid, flavonoid, dan terpenoid, yang dapat menghambat pertumbuhan berbagai bakteri, termasuk Streptococcus mutans sehingga obat kumur kemungkinan memiliki aktivitas antibakteri. Pelarut aman yang banyak digunakan untuk ekstraksi komponen fitokimia tersebut adalah etanol 70-80\%. Penentuan daya antibakteri dapat dilakukan menggunakan metode difusi agar atau pengenceran. Ekstrak daun Ketul berpotensi digunakan dalam formula obat kumur herbal. Selain potensi antibakterinya, karakteristik lainnya dapat diatur untuk memenuhi syarat formula obat kumur herbal yaitu pH berkisar 5-7, nilai viskositas mendekati nilai viskositas air (1cP), stabilitas dapat tetap terjaga selama penyimpanan dan kemungkinan obat kumur berwarna kuning kecoklatan. Beberapa bahan tambahan, seperti sorbitol, tween-80, peppermint oil, dan natrium benzoate, merupakan bahan tambahan yang aman dan umum digunakan untuk menambah cita rasa dan stabilitas formula obat kumur herbal ekstrak daun Ketul.
\end{abstract}

Kata kunci: aktivitas antibakteri, gulma, pelarut, streptococcus mutans

\section{PENDAHULUAN}

Mulut merupakan tempat yang sangat ideal bagi perkembangan bakteri. Bila tidak dibersihkan dengan sempurna, sisa makanan yang terselip bersama bakteri akan bertambah banyak dan membentuk koloni yang disebut plak. Bakteri utama penyebab timbulnya plak adalah streptococcus mutans, yang merupakan penghuni normal rongga mulut. Bakteri tersebut akan bertumbuh subur dan menjadi patogen, bila berada dalam lingkungan hidup yang mendukung pertumbuhannya. Plak merupakan tempat pertumbuhan bakteri streptococcus mutans yang memproduksi asam laktat. Jika tidak dibersihkan dengan baik, asam laktat tersebut akan menghancurkan email gigi dan akhirnya menyebabkan karies gigi.

Menjaga kebersihan mulut dan gigi dengan melakukan penghapusan akumulasi plak pada permukaan gigi secara teratur adalah cara yang efektif untuk mencegah karies gigi dan periodontal (Ocheng, 2015). Obat kumur memiliki kemampuan untuk memberikan efek terapeutik di seluruh permukaan gigi termasuk daerah yang tidak dapat dijangkau oleh sikat gigi. Obat kumur adalah cairan yang mengandung anti-inflamasi, anti-mikroba, dan aksi analgesik (Singh, Kaur, \& Singh, 2017).

Meskipun obat kumur chlorhexidine mengandung anti-bakteri untuk mengontrol plak, namun tidak dapat digunakan untuk jangka waktu yang lama karena memiliki beberapa efek samping seperti perubahan rasa, pembentukan kalkulus supragingiva, deskuamasi mukosa 
mulut dan juga penggunaannya yang terbatas pada pasien anak, serta dapat menyebabkan pewarnaan ekstrinsik saat meminum minuman seperti teh dan kopi. Penggunaan bahan alami merupakan alternatif untuk mengatasi dampak negatif yang ditimbulkan oleh bahan sintetik. Banyak ekstrak tanaman memiliki sifat anti-mikroba yang secara efektif digunakan dalam menjaga kebersihan mulut yang baik (Singh et al, 2017).

Ketul (Bidens pilosa) adalah tanaman dari famili Asteraceae yang dapat ditemukan di seluruh dunia. Tanaman ketul merupakan salah satu tanaman yang digunakan masyarakat sebagai obat herbal. Dalam pengobatan traditional, ketul digunakan untuk mengobati infeksi mata, mimisan, demam kuning, diare, luka, maag (Namukobe et al., 2011); permasalahan gigi (Lense, 2012), (Singh et al., 2017), (Ocheng, 2015); pembengkakan limpa (Arthur, Naidoo and Coopoosamy, 2012); penurun panas, anti radang, wasir, radang kulit, flu, demam, luka digigit ular, rheumatik sakit kepala, perut kembung, sariawan. Seluruh bagian dari tanaman ketul seperti daun, bunga, biji, batang, dan/atau akar digunakan sebagai komponen obat herbal (Singh et al., 2017), (Xuan \& Khanh, 2016), (Dharmananda, 2013).

Secara tradisional, ketul telah digunakan sebagai makanan tanpa efek samping yang nyata (Liang et al., 2020), (Xuan \& Khanh, 2016). Dari studi toksisitas, pemberian ketul sangat aman bagi kesehatan hewan percobaan (tikus) dan hewan sasaran (ayam) (Liang et al., 2020). Konsumsi ekstrak berair B. pilosa hingga $1 \mathrm{~g} / \mathrm{kg}$ Berat Badan/hari, sangat aman pada tikus percobaan (Yang, 2014). Berbagai jenis preparasi ekstrak dari tanaman ini memiliki aktivitas biologis dan farmakologis seperti aktivitas antibakteri, antiinflamasi, aktivitas antialergi, aktivitas antimalaria, modulator sel T, anti-hypertensive, antikanker, antivirus, antipiretik, antibiotik dan antioksidan (Xuan \& Khanh, 2016), (Bartolome, Villaseñor, \& Yang, 2013), (Bairwa et al., 2010).

Pada studi tentang keberhasilan antibakteri ekstrak daun ketul terhadap bakteri mulut pasien HIV/AIDS secara in-vitro diperoleh bahwa ekstrak akuades dan ekstrak etanol dari daun Ketul memiliki konsentrasi hambat minimum (Minimum Inhibitory Concentration/MIC)

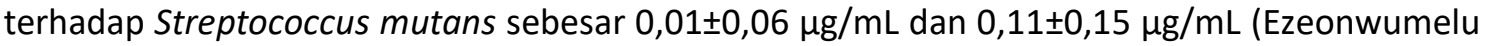
et al., 2017). Beberapa studi lain juga membuktikan aktivitas antibakteri tanaman ini. Minyak esensial dari Ketul juga terbukti dapat menghambat Streptococcus mutans pada konsentrasi $1 \%$ (p 0,0005); 0,1\% (0,0006); dan 0,01\% (0,0013) (Ocheng, 2015). Ekstrak daun Ketul juga memiliki kelebihan karena aktivitas analgesik, antiinflamasi dan mengurangi sakit pada lesi (semacam sariawan) di mulut pada pasien HIV/AIDS (Ezeonwumelu et al., 2018).

Berdasarkan hal-hal tersebut, maka tumbuhan ketul memiliki banyak potensi untuk dikembangkan termasuk untuk formula obat kumur herbal. Tujuan penelusuran pustaka ini adalah untuk memberikan gambaran tentang formulasi obat kumur yang menggunakan ekstrak daun Ketul sebagai bahan aktif antibakteri terhadap Streptococcus mutans dengan penambahan bahan additif seperti sorbitol, peppermint oil, tween-80, dan natrium benzoat dalam formulanya.

\section{METODE}

Pada penelusuran pustaka ini, metode yang digunakan adalah penelusuran informasi berupa dasar teori dan data penelitian yang berkaitan dengan formulasi obat kumur meliputi kandungan kimia daun ketul (Bidens pilosa) yang berpotensi sebagai antibakteri, metode ekstraksi senyawa berkhasiat antibakteri dari daun Ketul, metode uji antibakteri yang tepat untuk formula obat kumur, formulasi obat kumur ekstrak daun ketul dan parameter karakteristik obat kumur.

\section{HASIL DAN BAHASAN}

Hasil penelusuran pustaka dipilah dalam beberapa bagian dan disajikan sebagai berikut. 


\section{Kandungan Kimia Daun Ketul yang Berpotensi Sebagai Antibakteri}

Dari penelusuran pustaka diketahui bahwa ketul mengandung beberapa senyawa fitokimia yang terbukti dapat menghambat pertumbuhan berbagai bakteri. Dalam ekstrak etanol daun ketul (Bidens pilosa), yang berpotensi sebagai antibakteri adalah tannin (komponen fitokimia paling banyak ditemukan), glikosida jantung, saponin, alkaloid, steroid, dan flavonoid (Nakibuule et al., 2019). Ekstrak daun ketul juga terbukti mengandung flavonoid yang aktif menghambat pertumbuhan bakteri yang resisten terhadap obat antibiotika, seperti Pseudomonas aeruginosa, Staphylococcus aureus, Streptococcus pneumoniae dan Staphylococcus epidermidis yang resisten terhadap obat antibiotika (Nakibuule et al., 2019), (Silva et al., 2014) (Tabel 1). Ekstrak ketul juga mampu menghambat bakteri dari mulut pasien HIV/AIDs atau bakteri mulut yang biasanya dapat menyebabkan terbentuknya plak gigi dan penyakit gingivitis, seperti Streptococcus mutans, Streptococcus pneumoniae, Escherichia coli, Staphylococcus aureus, Staphylococcus saprophyticus, Bacillus cereus, non-haemolytic Streptococcus, Salmonella pullorum dan Klebsiella pneumoniae (Ezeonwumelu et al., 2017).

Senyawa bioaktif tersebut menghambat pertumbuhan bakteri dengan beberapa mekanisme. Tanin menghambat pertumbuhan bakteri (Redondo et al., 2014), karena menyebabkan denaturasi protein dan menurunkan tegangan permukaan sel sehingga permeabilitas dinding sel bakteri meningkat. Kerusakan dan peningkatan permeabilitas sel bakteri menyebabkan pertumbuhan sel terhambat dan akhirnya dapat menyebabkan kematian sel. Sedangkan flavonoid, mempunyai kemampuan berinteraksi dengan deoxyribonucleic acid (DNA) bakteri, menyebabkan kerusakan fungsi membrane sitoplasma, menghambat metabolism energi, menghambat pembentukan biofilm, menghambat porin membrane sel, mengubah permeabilitas membrane dan melemahkan patogenitas sel bakteri (Xie et al., 2014). Saponin berfungsi untuk memengaruhi membran sitoplasma sehingga sel mikroba menjadi rusak (Arabski et al., 2012). Tanin adalah zat polifenol tumbuhan yang memiliki rasa pahit dan merupakan komponen fitokimia yang dapat mengendapkan protein dan dapat menyebabkan warna kuning hingga kecoklatan dalam larutan air (Ashok \& Upadhyaya, 2012). Jumlah tanin yang tinggi memungkinkan ekstrak etanol daun Ketul dapat digunakan dalam pembuatan obat untuk treatment infeksi bakteri (Owoyemi et al., 2017) (Owoyemi \& Oladunmoye, 2017).

Tabel 1

Kandungan Fitokimia Daun Ketul dan Aktivitas Antibakterinya

\begin{tabular}{|c|c|c|c|}
\hline Pelarut & Kandungan kimia & Aktiv terhadap & Pustaka \\
\hline Air & $\begin{array}{l}\text { Alkaloid, Flavonoid, flavonol, } \\
\text { glikosida, saponin, tannin, } \\
\text { terpenoid, steroid dan sterol }\end{array}$ & $\begin{array}{l}\text { Staphylococcus aureus, } \\
\text { Escherichia coli, } \\
\text { Pseudomonas aeruginosa, } \\
\text { Salmonella enteritidis, S. } \\
\text { tyhpi, S. paratyhpi dan S. } \\
\text { typhimurium }\end{array}$ & $\begin{array}{l}\text { (Lawal, } \\
\text { Grierson and } \\
\text { Afolayan, } \\
\text { 2014) }\end{array}$ \\
\hline $\begin{array}{c}\text { Etanol } \\
70 \%\end{array}$ & fenol dan flavonoid & $\begin{array}{l}\text { Staphylococcus aureus, } \\
\text { Bacillus cereus ATCC } 10876, \\
\text { Staphylococcus epidermidis } \\
\text { ATCC13518, Enterococcus } \\
\text { faecalis ATCC } 49532, \\
\text { Escherichia coli ATCC } 35218, \\
\text { Shigella flexinerii ATCC } 12022\end{array}$ & $\begin{array}{l}\text { (Falowo et } \\
\text { al., 2016) }\end{array}$ \\
\hline $\begin{array}{c}\text { Etanol } \\
70 \%\end{array}$ & $\begin{array}{l}\text { Alkaloid, flavonoid, tannin, } \\
\text { saponin }\end{array}$ & $\begin{array}{l}\text { Staphylococcus aureus yang } \\
\text { peka dan resisten oksasillin }\end{array}$ & $\begin{array}{l}\text { (Silva et al., } \\
\text { 2014) }\end{array}$ \\
\hline Metanol & tannin; flavonoid; alkaloid; & Bacillus subtilis, Escherichia & (Ajanaku et \\
\hline
\end{tabular}


karbohidrat; quinone; glikosida; glikosida jantung; terpenoid; cis9-hexadecenal; 9-Oxabicyclo [6.1.0] nonane; hexadecanoic acid, methyl ester; Dodecanoic acid; 10,13-Octadecadienoic acid, methyl ester; 9,12,15-

Octadecatrienoic acid, methyl ester(Z,Z,Z)-; Tetradecanal; 2Methyl-Z,Z-3,13-octadeca-dienol; 13-Octadecenal, (Z)-; Oleic Acid Fenol dan flavonoid, termasuk 1H-3A, 7-Methanozulene; 1,3,6,10-Dodecatetraene, 3,7,11trimethyl-(Z,E); Octahydro-

Metanol 1,4,9,9-tetramethyl; 9HFluorene,9-Diazo; 1-Octadecyne; $\mathrm{N}-H$ exadecanoic acid dan 3,7,11,15-Tetramethyl-2Hexadecen-1-ol. flavonoid, alkaloid, karbohidrat antosianin dan betasiaanin,

Heksan quinon, glikosida jantung, terpenoid, triterpenoid, koumarin, dan steroid.

Heksan/ Tidak ada informasi
metanol

Metanol: n-heksan flavonoid (1:2: v/v)

$\begin{array}{ll}\begin{array}{c}\text { Dikhloro } \\ \text { metan }\end{array} & \begin{array}{l}\text { tannin, alkaloid, glikosida } \\ \text { jantung, terpenoid, triterpenoid, } \\ \text { fenol, koumarin, steroid }\end{array} \\ \text { etil } & \begin{array}{l}\text { tannin, alkaloid, glikosida } \\ \text { asetat }\end{array} \\ \begin{array}{l}\text { jantung, terpenoid, triterpenoid, } \\ \text { fenol, steroid }\end{array}\end{array}$

coli, Klebsiella pneumoniae, al., 2018)

Pseudomonas aeruginosa, Candida, Rhizopus sp.
Staphylococcus aureus,

Micrococcus luteus and Pseudomonas aeruginosa, Candida albicans, Escherichia

(Singh et al., 2017) coli,
Bacillus subtilis dan
Candida albicans
(Ajanaku et
al., 2018)

(Ajanaku et

Mycobacterium tuberculosis al., 2018)

Pseudomonas aeruginosa ATCC $^{\circledR} 27853^{\text {TM }}$ yang peka dan resistan obat, Staphylococcus aureus ATCC $^{\circledR} 25923^{\mathrm{TM}}$, yang peka dan resistan methicillin, Staphylococcus epidermidis. Streptococcus pneumoniae resisten methicillin,

$\begin{array}{lc}\text { Candida albicans } & \begin{array}{c}\text { (Ajanaku et } \\ \text { al., 2018) }\end{array} \\ \begin{array}{l}\text { Rhizopus sp., Bacillus subtilis, } \\ \text { Pseudomonas aeruginosa }\end{array} & \begin{array}{c}\text { (Ajanaku et } \\ \text { al., 2018) }\end{array}\end{array}$

(Nakibuule et al., 2019)

\section{Metode Ekstraksi Senyawa Berkhasiat Antibakteri dari Daun Ketul}

Pada pemakaian secara tradisional, masyarakat menggunakan air untuk seduhan daun ketul (Bidens pilosa) atau dalam etanol untuk pemakaian luar. Berdasarkan hasil penelusuran pustaka, beberapa senyawa dengan aktivitas antibakteri diperoleh dari ekstraksi daun ketul menggunakan beberapa pelarut, yaitu air, etanol 70-80\%, methanol, heksan, diklorometan dan etil asetat (Tabel 1). Metanol banyak digunakan tetapi methanol merupakan pelarut yang harus dihindari untuk aplikasi oral. Pemakaian methanol dapat digantikan dengan etanol yang memiliki polaritas yang mendekati sama dengan methanol. Etanol juga digunakan di beberapa literatur dan pelarut air juga mampu mengekstrak kandungan berkhasiat antibakteri. Owoyemi dan Oladunmoye (2017), menggunakan pelarut etanol yang terbukti dapat mengekstrak lebih 
banyak kandungan fitokimia dari daun ketul dibandingkan dengan pelarut akuades atau kloroform. Dari seluruh komponen fitokimia ekstrak etanol daun ketul yang berpotensi sebagai antibakteri, tanin merupakan komponen fitokimia paling banyak dihasilkan melalui ekstraksi etanol daun Ketul, diikuti glikosida jantung, saponin, alkaloid, flavonoid, dan steroid (Owoyemi et al., 2017), (Falowo et al., 2016), (Silva et al., 2014).

Secara umum, metode ekstraksi yang digunakan untuk mengekstrak tanaman adalah maserasi yang tergolong dalam metode ekstraksi pelarut (Zhang, Lin, \& Ye, 2018), (Cowan, 1999). Teknik ini digunakan karena memiliki jumlah langkah yang sederhana dan jumlah hasil ekstraksi yang termasuk banyak dalam proses ekstraksi manual terhadap senyawa yang memiliki gugus $-\mathrm{OH}$ dan karbonil menggunakan alkohol dan air. Untuk melarutkan golongan minyak volatil, saponin dan polisakarida digunakan pelarut berupa air, sedangkan pada golongan tanin dan polifenol menggunakan ekstraksi pelarut alcohol (Cowan, 1999).

Faktor-faktor yang dapat meningkatkan difusivitas dan kelarutan pada tahapan ekstraksi akan memfasilitasi ekstraksi. Sifat-sifat pelarut, ukuran partikel produk, rasio pelarut-padatan, suhu ekstraksi, dan lama ekstraksi akan mempengaruhi efisiensi ekstraksi (Zhang et al, 2018). Berdasarkan kelarutannya, pelarut dengan nilai polaritas yang mendekati polaritas zat terlarut cenderung berkinerja lebih baik dan sebaliknya; alkohol adalah pelarut universal dalam ekstraksi pelarut untuk penyelidikan fitokimia. Efisiensi ekstraksi dapat ditingkatkan dengan ukuran partikel yang kecil, suhu tinggi, memperbesar rasio pelarut terhadap padatan, serta bertambahnya durasi ekstraksi.

Pada studi skrining fitokimia menggunakan metode Green (Owoyemi et al., 2017), maka dapat dilakukan proses berikut ini. Daun ketul dicuci kemudian dikeringkan pada suhu ruangan $\left(25 \pm 2{ }^{\circ} \mathrm{C}\right)$ selama 2 minggu kemudian digiling dengan mesin untuk menurunkan ukuran partikel dan disaring dengan ayakan ukuran 1,18 mm. Ekstraksi daun ketul menggunakan pelarut dengan perbandingan antara pelarut dan daun Ketul 10:1 (v/w). Daun ketul direndam pada etanol, akuades, dan kloroform pada suhu kamar selama 72 jam dan diaduk secara teratur. Selanjutnya ekstrak disaring menggunakan kertas saring Whatman. Filtrat diperoleh dengan menghilangkan pelarut menggunakan rotary evaporator pada suhu $40^{\circ} \mathrm{C}$.

\section{Formulasi Obat Kumur dengan Bahan Aktif Ekstrak Daun Ketul}

Formulasi obat kumur ekstrak daun ketul dilakukan dengan mencampur agen antimikroba ekstrak daun ketul dengan akuades untuk pengenceran dan menambahkan beberapa bahan aktif lain yaitu sorbitol, tween-80, peppermint oil, dan sodium-benzoat. Bahan-bahan tambahan tersebut umum ditemukan pada campuran obat kumur dan setiap bahan memiliki peran yang berbeda-beda dalam memengaruhi karakteristik produk akhir obat kumur ekstrak daun ketul yang tengah diformulasikan.

Obat kumur herbal bisa berisi beberapa ekstrak di dalamnya dengan kadar yang bervariasi sesuai keperluan (Ahmad et al., 2018). Kadar ekstrak yang ditambahkan bervariasi tergantung dari kekuatan antibakteri-nya, misalnya obat kumur pandan wangi berisi kadar ekstrak hingga 20\% (Komala, Nur'aini \& Indriati, 2017); ekstrak daun jambu biji 2,5-3,5\% (Handayani, Sundu, \& Sari, 2018). Kadar ekstrak daun kemangi yang ditambahkan antara 3-7\% sudah terbukti dapat menghambat pertumbuhan bakteri (Hidayanto et al., 2017).

\section{Peran Beberapa Bahan Tambahan Dalam Formula Herbal Obat Kumur}

Beberapa bahan tambahan untuk obat kumur antara lain adalah sorbitol, peppermint oil, tween dan natrium benzoate. Berdasarkan literatur, ekstrak daun ketul tidak memiliki rasa manis yang cukup karena kandungan gulanya rendah. Adanya gula sederhana seperti glukosa dapat difermentasi oleh bakteri mulut dan menyebabkan carries gigi. Sorbitol termasuk golongan pemanis alternatif dengan nilai relativitas rasa manis mendekati glukosa sebesar 0,6 (Sheet et al., 2014), (Soesilo, Santoso, \& Diyatri, 2006), tidak mahal dan aman untuk digunakan, serta sulit untuk difermentasi oleh bakteri plak gigi (Soesilo et al, 2006). Sorbitol 
adalah gula alkohol yang bersifat low-cariogenic (Nadimi et al., 2011). Proses fermentasi sorbitol berlangsung amat lambat karena sorbitol bukanlah medium yang baik bagi pertumbuhan bakteri dan tidak menurunkan $\mathrm{pH}$ saliva. Struktur kimia sorbitol tidak memungkinkan enzim glukosiltransferase dari Streptococcus mutans memecah rantai sorbitol menjadi asam laktat, asam asetat, serta asam format. Selanjutnya, sorbitol dapat dikatalisis oleh enzim sorbitol dehidrogenase tubuh manusia yang kemudian diubah menjadi fruktosa. Fruktosa tidak dapat masuk ke siklus asam piruvat sehingga tidak akan dihasilkan asam laktat, asam format ataupun etanol yang membuat $\mathrm{pH}$ saliva menjadi asam (Soesilo, Santoso and Diyatri, 2006).

Peppermint oil adalah minyak esensial yang umum dicampurkan dalam formula obat kumur dan pasta gigi karena dapat memberikan kesegaran, mencegah bau mulut, serta menghilangkan plak (Fayed, 2019). Minyak esensial dan daun peppermint oil memiliki aktivitas antibakteri yang kuat terhadap Streptococcus mutans dan Lactobacili penyebab karies gigi. Peppermint oil memiliki aroma mentol yang segar dan tajam, berwarna bening hingga kuning pucat dengan viskositas yang encer.

Tween-80 merupakan surfaktan yang tidak toksik, ramah lingkungan, biokompatibel, dan murah secara komersial. Surfaktan merupakan agen yang memengaruhi pembentukan dan stabilitas emulsi. Selain itu, tween-80 dapat digunakan sebagai agen pelarut untuk beberapa zat termasuk minyak esensial (Prieto \& Calvo, 2013). Penambahan konsentrasi tween-80 tidak memiliki pengaruh signifikan terhadap nilai massa jenis obat kumur (Yosephine et al., 2015), karena nilai massa jenis tween-80 hampir sama dengan nilai massa jenis air yaitu sebesar 1,06-1,09 $\mathrm{g} / \mathrm{ml}$.

Natrium benzoat adalah garam natrium dengan rumus kimia $\mathrm{C}_{7} \mathrm{H}_{5} \mathrm{O}_{2} \mathrm{Na}$ dan berat molekul $144,1 \mathrm{~g} / \mathrm{mol}$; tidak berbau, dan larut dalam air dan etanol. Natrium benzoat digunakan sebagai pengawet beberapa produk kosmetik, farmaseutikal, dan makanan karena aman, larut sempurna dalam air dan memiliki stabilitas yang baik (Lennerz et al., 2015 dalam Linke, Casagrande, \& Cardoso, 2018); serta aktif sebagai pengawet antimikroba pada pH 2-4 (Rowe et al., 2009 dalam Dewi, 2017). Selain itu, natrium benzoat mampu menghambat pertumbuhan dari kapang, yeast, dan bakteri yang umumnya dapat tumbuh pada berbagai produk termasuk obat kumur (Ren et al., 2014 dalam Linke, Casagrande et al, 2018). Natrium benzoate dapat mendispersikan karbohidrat, lemak dan protein sehingga melemahkan perlekatan plak sehingga gigi mudah dibersihkan (Parashar, 2015).

\section{Parameter dan Karakteristik Obat Kumur}

Dalam memformulasikan obat kumur ekstrak daun ketul (Bidens pilosa), perlu memperhatikan beberapa karakteristik sebagai parameter esensial obat kumur seperti nilai $\mathrm{pH}$, viskositas, dan stabilitas obat kumur agar obat kumur ekstrak daun ketul tersebut dapat digunakan secara efektif sesuai dengan fungsinya.

\section{pH Obat kumur ekstrak daun ketul}

$\mathrm{pH}$ obat kumur ekstrak daun Ketul hasil formulasi sebaiknya berada pada range 5-7. Pengaturan $\mathrm{pH}$ dimaksudkan untuk mencegah perubahan $\mathrm{pH}$ yang mendukung terbentuknya biofilm oral (Kilian et al., 2016). Menurut (Cai et al., 2016) penyakit yang berhubungan dengan biofilm oral dapat dikaitkan dengan adanya bakteri kariogenik dan konsumsi karbohidrat yang tinggi, terutama sukrosa. Fermentasi sukrosa oleh bakteri mulut dapat dengan cepat menurunkan $\mathrm{pH}$ rongga mulut, yang mengakibatkan pergeseran keseimbangan mikroflora oral menjadi lebih kariogenik.

\section{Viskositas ekstrak daun ketul}

Viskositas merupakan salah satu parameter obat kumur yang penting. Viskositas adalah ukuran kekentalan medium pendispersi suatu larutan, semakin dekat tingkat viskositas obat 
kumur dengan viskositas air, maka obat kumur tersebut akan semakin mudah dan nyaman digunakan untuk berkumur (Ningrum and Waznah, 2018). Perbedaan konsentrasi dan jenis bahan campuran yang digunakan akan mempengaruhi massa jenis obat kumur (Handayani, Warnida \& Nur, 2016; Hidayanto et al., 2017). Semakin besar nilai massa jenis suatu cairan semakin tinggi pula nilai viskositasnya (Handayani, Warnida, \& Nur, 2016).

\section{Prediksi karakteristik organoleptis obat kumur herbal daun ketul}

Umumnya obat kumur yang berisi ekstrak tanaman berwarna kecoklatan (Ahmad et al., 2018; Komala, Nur'aini, \& Indriati, 2017), atau hijau pekat cenderung coklat (Handayani, Sundu, \& Sari, 2018; Hidayanto et al., 2017). Kemungkinan hal ini disebabkan karena keberadaan tannin. Tanin adalah zat polifenol tumbuhan yang memiliki rasa pahit dan merupakan komponen fitokimia yang dapat mengendapkan protein dan dapat menyebabkan warna kuning hingga kecoklatan dalam larutan air (Ashok \& Upadhyaya, 2012). Keberadaan tannin dalam ekstrak etanol daun Ketul diprediksi dapat menyebabkan larutan obat kumur ekstrak daun Ketul (Bidens pilosa) akan berwarna kuning hingga kecoklatan dan memiliki sedikit rasa pahit sesuai kadar ekstrak dalam obat kumur. Oleh karena itu diperlukan pemanis dalam formula obat kumur untuk menutupi rasa pahit. Sorbitol merupakan bahan pemanis yang cukup mewakili untuk ditambahkan.

\section{Stabilitas obat kumur ekstrak daun ketul}

Observasi $\mathrm{pH}$ dan visualisasi fisik produk obat kumur selama penyimpanan perlu dilakukan, meliputi homogenitas dan kejernihan larutan, rasa, aroma dan warna. Hal ini untuk melihat stabilitas hasil formula obat kumur ekstrak daun Ketul. Stabilitas produk farmasi dan kosmetik dapat didefinisikan sebagai kemampuan suatu produk untuk bertahan dalam batas yang ditetapkan sepanjang periode penyimpanan dan penggunaan, sifat dan karakteristiknya sama dengan yang dimilikinya pada saat dibuat. Hal ini dilakukan untuk menentukan kelayakan dan keamanan produk hasil formulasi. Berbagai faktor dapat memengaruhi stabilitas hasil formula ekstrak daun Ketul. Faktor-faktor fisika seperti panas, cahaya dan kelembaban, mungkin akan menyebabkan atau mempercepat reaksi kimia (Dewi, 2017). Selain itu, adanya kontaminasi mikroorganisme dapat menyebabkan perubahan rasa, warna, bau spesifik, bercak-bercak miselium, kekeruhan warna, perubahan $\mathrm{pH}$, dan lain-lain (Dewi, 2017).

Stabilitas obat kumur herbal mengandung berbagai ekstrak tanaman terbukti stabil, walaupun viskositas obat kumur daun salam tidak stabil selama penyimpanan selama 2 minggu (Handayani et al, 2016). Pada umumnya, obat kumur berisi ekstrak tumbuhan stabil secara fisik. Obat kumur berisi ekstrak daun kemangi terbukti stabil secara fisik (Ningrum \& Waznah, 2018). Begitu juga dengan obat kumur jus nanas (Wahyuningsih \& Auliah, 2020). Stabilitas obat kumur ekstrak kemangi juga terbukti stabil fisik berdasarkan metode shock thermic (Yosephine et al., 2015), (Justicia, Ferdinan, \& Maya, 2017). Stabilitas organoleptis obat kumur ekstrak daun jambu biji juga terbukti stabil pada penyimpanan selama 3 minggu (Handayani et al, 2018).

\section{SIMPULAN}

Dari hasil penelusuran pustaka dapat disimpulkan bahwa ekstrak daun Ketul berpotensi digunakan dalam formula obat kumur herbal. Daun ketul (Bidens pilosa) dan kemungkinan obat kumur herbalnya mengandung tannin, glikosida jantung, saponin, alkaloid, flavonoid, dan terpenoid, yang dapat menghambat pertumbuhan berbagai bakteri, termasuk Streptococcus mutans. Pelarut aman yang banyak digunakan untuk ekstraksi komponen fitokimia tersebut adalah etanol $70-80 \%$. Selain potensi antibakterinya, karakteristik lainnya dapat diatur untuk memenuhi syarat formula obat kumur herbal yaitu pH berkisar 5-7, nilai viskositas mendekati nilai viskositas air $(1 \mathrm{cP})$, stabilitas dapat tetap terjaga selama penyimpanan dan kemungkinan obat kumur berwarna kuning kecoklatan. Beberapa bahan tambahan, seperti sorbitol, tween80, peppermint oil, dan natrium benzoat, merupakan bahan tambahan yang aman dan umum 
digunakan untuk menambah cita rasa dan stabilitas formula obat kumur herbal ekstrak daun Ketul.

\section{SARAN}

Untuk membuktikan potensinya dan mengetahui formula obat kumur ekstrak daun Ketul yang optimum, maka perlu dilakukan formulasi dan optimasi terhadap obat kumur ekstrak daun Ketul lebih lanjut secara wet lab.

\section{Ucapan Terima Kasih}

Penelitian ini didanai oleh hibah Program Kreativitas Mahasiswa Penelitian Eksakta (PKMPE), Direktorat Pembelajaran dan Kemahasiswaan, Direktorat Jenderal Pendidikan Tinggi.

\section{REFERENSI}

Ahmad, S. et al. (2018) 'Formulation and Evaluation of Antibacterial Herbal Mouthwash Against Oral Disorders', Indo Global Journal of Pharmaceutical Sciences, 08(02), pp. 37-40. doi: 10.35652/igjps.2018.3740.

Ajanaku, C. et al. (2018) 'In-vitro antibacterial, phytochemical, antimycobacterial activities and GC-MS analyses of Bidens pilosa leaf extract', Journal of Microbiology, Biotechnology and Food Sciences, 8(1), pp. 721-725. doi: 10.15414/jmbfs.2018.8.1.721-725.

Arabski, M. et al. (2012) 'Effects of saponins against clinical E. coli strains and eukaryotic cell line', Journal of Biomedicine and Biotechnology, 2012, p. 6 pages. doi: 10.1155/2012/286216.

Arthur, G. D., Naidoo, K., \& Coopoosamy, R. M. (2012) 'Bidens pilosa L.: Agricultural and pharmaceutical importance', Journal of Medicinal Plants Research, 6(17), pp. 3282-3287. doi: 10.5897/jmpr12.195.

Ashok, P. K., \& Upadhyaya, K. (2012) 'Tannins are Astringent', Journal of Pharmacognosy and Phytochemistry, 1(3), pp. 45-50. Available at: https://www.phytojournal.com/vol1Issue3/Issue_sept_2012/8.1.pdf.

Bairwa, K. et al. (2010) 'An updated review on Bidens pilosa L.', Der Pharma Chemica, 2(3), pp. 325-337. Available at: https://www.derpharmachemica.com/pharma-chemica/an-updatedreview-on-bidens-pilosa-I.pdf.

Bartolome, A. P., Villaseñor, I. M., \& Yang, W. C. (2013) 'Bidens pilosa L. (Asteraceae): Botanical properties, traditional uses, phytochemistry, and pharmacology', Evidence-based Complementary and Alternative Medicine, 2013, pp. 1-51. doi: 10.1155/2013/340215.

Cai, J. N. et al. (2016) 'Functional relationship between sucrose and a cariogenic biofilm formation', PLOS ONE, 11(6), pp. 1-12. doi: 10.1371/journal.pone.0157184.

Cowan, M. M. (1999) 'Plant Products as Antimicrobial Agents', Clinical Microbilogy Review, 12(4), pp. 564-582. doi: 10.1590/s0006-87052004000200004.

Dharmananda, S. (2013) A Popular Remedy Ecapes Notice of Western Practitioners, Institute for Traditional Medicine, Portland, Oregon. Available at: http://www.itmonline.org/arts/bidens.htm (Accessed: 5 November 2020).

Dewi, D.P.M.S. (2017). Pengaruh Konsentrasi Pengawet Natrium Benzoat terhadap Karakeristik, Stabilitas Fisika \& pH pada Water Based Pomade yang Mengandung Ekstrak Aloe vera. Surabaya : Calyptra.

Ezeonwumelu, J. O. C. et al. (2017) 'In vitro Antibacterial Efficacy of Bidens pilosa, Ageratum conyzoides and Ocimum suave Extracts against HIV/AIDS Patients' Oral Bacteria in South- 
Western Uganda', Pharmacology \& Pharmacy, 08, pp. 306-323. doi: 10.4236/pp.2017.89023.

Ezeonwumelu, J. O. C. et al. (2018) 'Analgesic Appraisal of Bidens pilosa ( Asteraceae ) Leaf Extracts Used in Management of Oral Lesion Pain in HIV / AIDS Patients in Rodents', Pharmacology \& Pharmacy, 9, pp. 175-192. doi: 10.4236/pp.2018.96014.

Falowo, A. B. et al. (2016) 'In vitro antimicrobial activities of Bidens pilosa and Moringa oleifera leaf extracts and their effects on ground beef quality during cold storage and their effects on ground beef quality during cold storage', CyTA - Journal of Food. Taylor \& Francis, 14(4), pp. 541-546. doi: 10.1080/19476337.2016.1162847.

Falowo, D., \& Oladunmoye, M. (2018) 'Antibacterial Activity of Bidens pilosa Extracts on Escherichia coli 0157: H7 Isolated from Apparently Healthy Individuals', Asian Journal of Medicine and Health, 11(2), pp. 1-10. doi: 10.9734/ajmah/2018/34516.

Fayed, M. A. A. (2019) 'Mentha Piperita L. - a Promising Dental Care Herb Mainly Against Cariogenic Bacteria', Universal Journal of Pharmaceutical Research, 4(3), pp. 31-36. doi: 10.22270/ujpr.v4i3.271.

Handayani, F., Sundu, R., \& Sari, R. M. (2018) 'Formulasi dan uji aktivitas antibakteri streptococcus mutans dari sediaan mouthwash ekstrak daun jambu biji (Psidium guajava L.)', Jurnal Sains dan Kesehatan, 1(8), pp. 422-433. doi: 10.25026/jsk.v1i8.62.

Handayani, F., Warnida, H., \& Nur, S. J. (2016) 'Formulasi dan uji aktivitas antibakteri streptococcus mutans dari sediaan mouthwash ekstrak daun salam (Syzygium polyanthum (Wight) Walp.)', Media Sains, 9(1), pp. 74-84. Available at: https://Idikti11.ristekdikti.go.id/jurnal/pdf/d3246b40-3092-11e8-9030-54271eb90d3b/.

Hidayanto, A. et al. (2017) 'Formulasi Obat Kumur Ekstrak Daun Kemangi (Ocimum Basilicum L) dengan Pemanis Alami Stevia (Stevia Rebaudiana Bertoni)', University Research Colloquium, pp. 189-194. Available at: http://journal.ummgl.ac.id/index.php/urecol/article/view/1376/978.

Justicia, A. K., Ferdinan, A., \& Maya, M. (2017) 'Formulasi Mouthwash Minyak Atsiri Daun Kemangi (Ocimum sanctum L.) Dan Kayu Manis (Cinnamomum zeylanicum) Dengan Menggunakan Tween 80 Sebagai Surfaktan', Jurnal IImiah Ibnu Sina, 2(1), pp. 134-146. Available at: http://jiis.akfarisfibjm.ac.id/index.php?journal=JlIS\&page=article\&op=view\&path\%5B\%5D=91\&path\%5B\% $5 \mathrm{D}=64$.

Kilian, M. et al. (2016) 'The oral microbiome - An update for oral healthcare professionals', British Dental Journal, 221(10), pp. 657-666. doi: 10.1038/sj.bdj.2016.865.

Komala, O., Nur'aini, P., \& Indriati, D. (2017) 'Uji antibakteri sediaan obat kumur ekstrak daun pandan wangi (Pandanus amaryllifolius Roxb) terhadap Streptococcus mutans', Ekologia, 17(1), pp. 14-20. Available at: https://repository.unpak.ac.id/tukangna/repo/file/files20181110165035.pdf.

Lawal, I. O., Grierson, D. S., \& Afolayan, A. J. (2014) 'Phytotherapeutic information on plants used for the treatment of tuberculosis in Eastern Cape Province, South Africa', Evidencebased Complementary and Alternative Medicine, 2014, pp. 1-11. doi: $10.1155 / 2014 / 735423$.

Lense, O. (2012) 'The wild plants used as traditional medicines by indigenous people of Manokwari, West Papua', Biodiversitas, Journal of Biological Diversity, 13(2), pp. 98-106. doi: 10.13057/biodiv/d130208. 
Liang, Y. C. et al. (2020) 'Toxicity study of Bidens pilosa in animals', Journal of Traditional and Complementary Medicine. Elsevier Ltd, 10(2), pp. 150-157. doi: 10.1016/j.jtcme.2019.04.002.

Nadimi, H. et al. (2011) 'Are sugar-free confections really beneficial for dental health?', British Dental Journal. Nature Publishing Group, 211(7). doi: 10.1038/sj.bdj.2011.823.

Nakibuule, M. K. et al. (2019) 'Anti-bacterial Activity of Crude Flavonoid Fraction from Bidens pilosa Leaves against Selected Chronic Wound Bacterial Pathogens', Journal of Complementary and Alternative Medical Research, 8(October), pp. 1-13. doi: 10.9734/jocamr/2019/v8i130115.

Namukobe, J. et al. (2011) 'Traditional plants used for medicinal purposes by local communities around the Northern sector of Kibale National Park, Uganda', Journal of Ethnopharmacology. Elsevier Ireland Ltd, 136(1), pp. 236-245. doi: 10.1016/j.jep.2011.04.044.

Ningrum, W. A., \& Waznah, U. (2018) 'Formulasi mouthwash ekstrak etanol daun kemangi (Ocimumbasilicum L.)', Cendekia Journal of Pharmacy, 2(2), pp. 159-166. doi: 10.31596/cjp.v2i2.30.

Ocheng, F. (2015) 'Ugandan medicinal plants used traditonally for oral care: Investigation of extracts for anti-bacterial, cytotoxic and anti-inflammatory effects. Karolinska Institutet, Stockholm, Sweden and Makerere University, Kampala, Uganda. Available at: https://openarchive.ki.se/xmlui/bitstream/handle/10616/44839/Thesis_Francis_Ocheng.p df? sequence=1\&isAllowed=y.

Owoyemi, O. O. et al. (2017) 'Phytochemical Screening and Antibacterial Activities of Bidens pilosa L. and Tridax procumbens L. on Skin Pathogens Comparative Antimicrobial, anticholera and anticancer activities of Tridax procumbens and Bidens pilosa View project Molecular Biology View', International Journal of Modern Biology and Medicine J. Modern Biol. Med, 8(1), pp. 24-46. Available at: https://www.researchgate.net/publication/326981849.

Parashar, A. (2015) 'Mouthwashes and Their Use in Different Oral Conditions', Scholars Journal of Dental Sciences J. Dent. Sci, 2(2B), pp. 186-191. Available at: http://saspjournals.com/wp-content/uploads/2015/03/SJDS-22B186-191.pdf.

Prieto, C., \& Calvo, L. (2013) 'Performance of the Biocompatible Surfactant Tween 80, for the Formation of Microemulsions Suitable for New Pharmaceutical Processing', Journal of Applied Chemistry, 2013, pp. 1-10. doi: 10.1155/2013/930356.

Redondo, L. M. et al. (2014) 'Perspectives in the use of tannins as alternative to antimicrobial growth promoter factors in poultry', Frontiers in Microbiology, 5(MAR), pp. 1-7. doi: 10.3389/fmicb.2014.00118.

Sheet, B. S. et al. (2014) 'Some alternative sweeteners (xylitol, sorbitol, sucralose and stevia): Review', Karaelmas Science and Engineering Journal, 4(1), pp. 63-70. doi: 10.7212/zkufbd.v4i1.125.

Silva, da J. et al. (2014) 'In vitro screening antibacterial activity of bidens pilosa linné and annona crassiflora MART. Against oxacillin resistant staphylococcus aureus (ORSA) from the aerial environment at the dental clinic', Revista do Instituto de Medicina Tropical de Sao Paulo, 56(4), pp. 333-340. doi: 10.1590/S0036-46652014000400011.

Singh, G. et al. (2017) 'Pharmacological potential of Bidens pilosa L. and determination of bioactive compounds using UHPLC-QqQLIT-MS/MS and GC/MS', BMC Complementary and 
Alternative Medicine. BMC Complementary and Alternative Medicine, 17(1), pp. 1-16. doi: 10.1186/s12906-017-2000-0.

Singh, P., Kaur, M., \& Singh, I. (2017) 'Efficacy of Chlorhexidine vs Herbal mouthwash mouth wash in college students: A comparative study', International Journal of Medical and Health Research, 3(5), pp. 78-81. Available at: http://www.medicalsciencejournal.com/download/409/3-5-19-230.pdf.

Soesilo, D., Santoso, R. E. and Diyatri, I. (2006) 'Peranan sorbitol dalam mempertahankan kestabilan $\mathrm{pH}$ saliva pada proses pencegahan karies (The role of sorbitol in maintaining saliva's pH to prevent caries process)', Dental Journal (Majalah Kedokteran Gigi), 38(1), p. 25. doi: 10.20473/j.djmkg.v38.i1.p25-28.

Wahyuningsih, S., \& Auliah, N. (2020) 'Mouthwash jus buah nanas ( Ananas comosus L. Merr) terhadap bakteri streptococcus mutans', Jurnal Kesehatan, 13(2), pp. 171-177. doi: 10.24252/kesehatan.v13i2.16423.

Xie, Y. et al. (2014) 'Antibacterial Activities of Flavonoids: Structure-Activity Relationship and Mechanism', Current Medicinal Chemistry, 22(1), pp. 132-149. doi: 10.2174/0929867321666140916113443.

Xuan, T. D., \& Khanh, T. D. (2016) 'Chemistry and pharmacology of Bidens pilosa: an overview', Journal of Pharmaceutical Investigation. Springer Netherlands, 46(2), pp. 91-132. doi: 10.1007/s40005-016-0231-6.

Yang, W. (2014) 'Botanical, Pharmacological, Phytochemical, and Toxicological Aspects of the Antidiabetic Plant Bidens pilosa L', Evidence-Based Complementary and Alternative Medicine, 2014, pp. 1-14. doi: https://doi.org/10.1155/2014/698617.

Yosephine, A. D. et al. (2015) 'Mouthwash formulation of basil oil (Ocimum basilicum L.) and in vitro antibacterial and antibiofilm activities against streptococcus mutans', Majalah Obat Tradisional, 18(2), pp. 95-102. doi: 10.22146/tradmedj.8036.

Zhang, Q. W., Lin, L. G., \& Ye, W. C. (2018) 'Techniques for extraction and isolation of natural products: A comprehensive review', Chinese Medicine (United Kingdom). BioMed Central, 13(1), pp. 1-26. doi: 10.1186/s13020-018-0177-x. 